\title{
The Implementation Of Mind Mapping Technique to Improve Students Understanding in English Morphology
}

Mei Hardiah

Universitas Bengkulu

mhardiah@unib.ac.id

\begin{abstract}
This study aims to know how far the application of Mind Mapping technique is capable to improve students understanding on theoretical course such as English Morphology. The method of the research is experiment with queasy experiment applying nonequivalent control group design . Population of this research are odd semester students $\left(3^{\text {rd }}\right.$ semester) who take lecture on English Morphology course. There are two classes' namely experimental class which is treated with mind mapping technique and control class which is taught conventionally. After applying mind mapping technique in experimental class, the result is significantly different. The experiment class achievement from the test is better than the result of the test in the control class. Moreover based on the observation, the students from the class treated with mind mapping technique proved to be more motivated and enthusiastic in understanding the material. Student's center is also implemented in experimented class.
\end{abstract}

Keywords: Mind Mapping, Technique , English Morphology

\section{BACKGROUND}

One of the missions of the English Language Education Study Program FKIP UNIB is to produce professional English teachers who have good linguistic knowledge and qualified English language skills. In other words, a prospective English teacher must have good English language competence and excellent English-language performance. To achieve this mission, the curriculum in the English Education study program is divided into three fields of sciences designed to equip students to have competency and performance. The three fields of study are the fields of English teaching, English literature, and Linguistics.

In its division, the linguistics courses get a portion of almost $30 \%$ percent of the total courses offered. The courses in linguistics included Introduction to Linguistics, Phonetic and Phonology, English Morphology, Syntax, Semantics, Pragmatics, Discourse Analysis, Psycholinguistics, and Sociolinguistics. In general, linguistic courses are theoretical which aim to 
provide an understanding of linguistic concepts. Teaching theoretical subjects is a challenge for linguistic lecturers because they tend to be more serious and require more effort to attract students to understand the concepts in the courses offered.

Based on the experience in teaching linguistics courses, the difficulties faced were the ability of different students so that in teaching and learning activities in the class only a small percentage of students were actively involved and had the motivation to understand the subject matter. Even when group discussion and presentation methods were applied, students only partially involved actively while others tend to only listen, wait and receive information from the lecturer when giving an explanation in front of the class. This condition is exacerbated by the attitude of students who are lazy to make notes about important material explained. This is of course has an impact on student learning outcomes where there are still students with less grades (B-) and very few who get perfect grades (A / 85).

To overcome this problem, lecturers are expected to be able to apply creative learning methods to stimulate students to be more active and creative in order to motivate students participating in the subject of linguistics. The selection of the right teaching method will greatly influence the achievement of student understanding of linguistic concepts. Sudjana, (2005) defines learning methods as a way for teachers to build relationships with students in the teaching and learning process. A teacher or lecturer must be able to find the right learning method so that learning objectives can be achieved.

One of the method can be applied in linguistics course is Mind Mapping. According to Buzan (2012), Mind Mapping is a creative, effective way of recording so that we can express our thoughts. While Saleh (2009) describes Mind Mapping as a diagram used to describe a main theme and idea in the learning material. The application of the Mind Mapping method can help teachers / lecturers to provide explanations about material concepts to be explained with interesting and easy to understand illustrations. For students this method can be used to make notes in accordance with each student's imagination about the concepts of the material being taught. By applying this method it is expected that both lecturers and students are able to create a pleasant atmosphere in teaching and learning activities and full of enthusiasm to understand the material.

In summary, the Mind Mapping method can be described as the following diagram: 


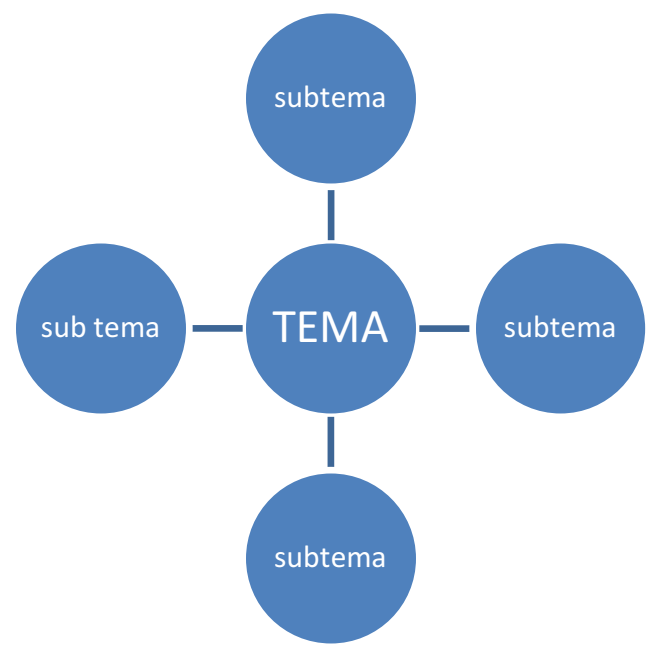

Then each sub-theme can be further elaborated with its branches. The use of images and selection of bright colors also include in Mind Mapping. Student's imagination is greatly appreciated by using this method.

By applying this method in the English Morphology course, students are expected to be more interested in the subject matter, making students active in making learning material notes and the results of group discussions, so that they can improve the memory of students who are correlated with learning outcomes. Some research on the application of the Mind method mapping in various subjects proved to be successful in improving student learning outcomes, among others, conducted by: Maisyarah et al (FKIP UNTAN), Shradda, B et al (2014). Lady Casco (2009), Anna buran (2015), Riswanto (2012).

The purpose of this study is to determine the extent of the application of the Mind Mapping method able to improve students' understanding of linguistic concepts in the English Morphology course. It also aims to increase students' understanding of the concepts of word formation in English in the English Morphology course. Moreover, it is expected to be able to contribute in improving the quality of learning in the English Education study program. Specifically for improving the ability of students to understand linguistic concepts in theoretical subjects. Students' understanding of the concept of forming English words in the English Morphology course will be seen based on the results of the post test after this method is applied to the experimental class and the control class. The research activity of the quasi-experiment compare the learning outcomes of 
students who get the treatment using the Mind method Mapping and Control classes without the Mind Mapping method.

\section{Mind Mapping Method}

The Mind Maps method was first developed by British Psychologist Tony Buzan in his late $60 \mathrm{~s}$ in his efforts to help students make notes effectively. According to Buzan, Mind Maps is a network that associates images and words. The use of colors, images, and numbers is very instrumental in producing mind maps. The procedure for designing a mind map according to Buzan starts with pictures and words in the middle of the paper, and then adds keywords that are related to the main topic. The use of images, colors, symbols, and dimensions is highly recommended to get emphasis and make it possible to recall. Alamsyah (2009) explains that Mind Mapping can work well because visual design allows students to see relationships between ideas, and motivates them to group certain ideas together. Mind Mappings prove to be better when created in groups where discussion between group members allows for diverse ideas to emerge and makes the task more lively and enjoyable.

Example of Mind Mapping chart:

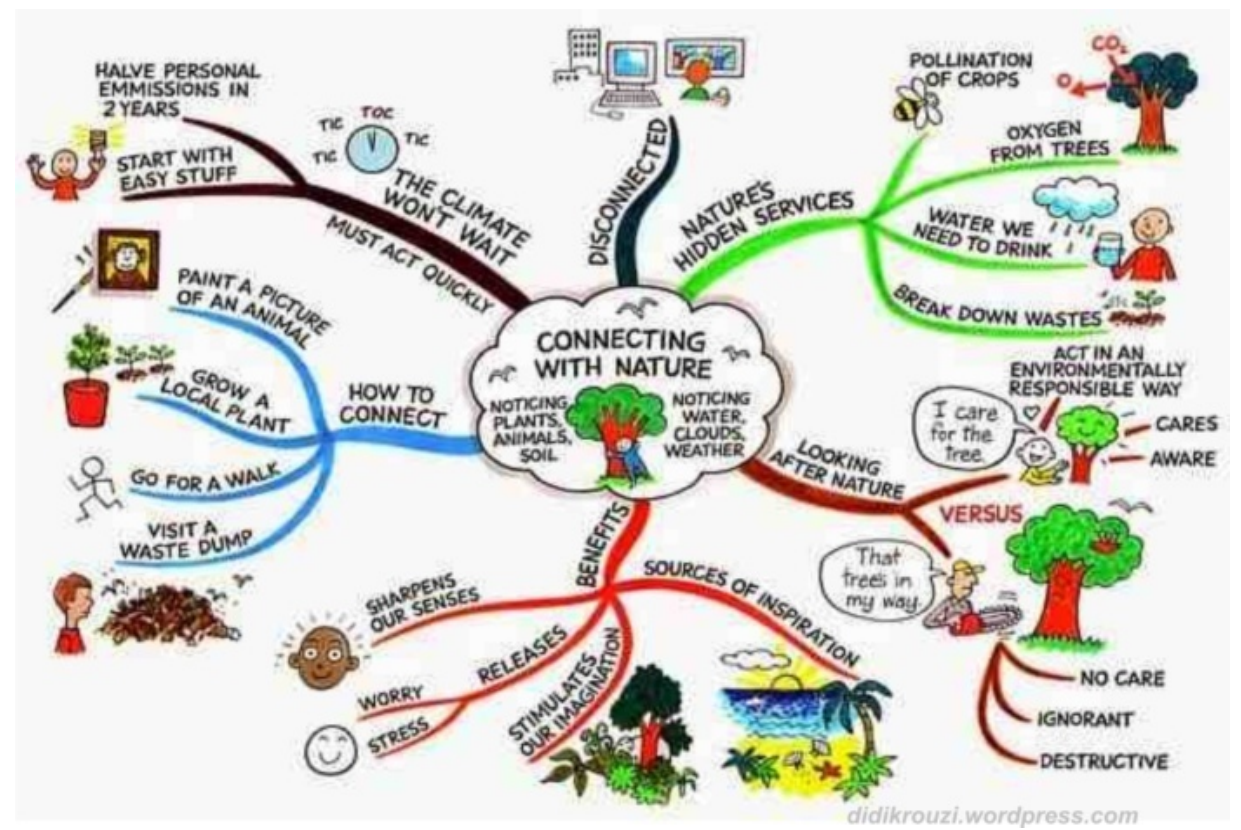

From the example of Mind Mapping above, it seems that creativity plays an important role in making the design of Mind Mapping. The use of colors and images makes the Mind Mapping chart more alive so that it is easier to remember.

\section{Mind Maps in Teaching Foreign Languages}


Mind Map in foreign language teaching first applied in the $90 \mathrm{~s}$ as a tool to activate certain knowledge and help students remember vocabulary Several studies on the application of the Mind Mapping method in foreign language teaching have been carried out, among others, to improve students' writing skills (Riswanto et al 2012), improve vocabulary skills, even in any field of science this method is proven to improve student understanding.

Tony Buzan presents 4 steps in creating a Mind Map, namely;

1. Prepare plain paper to be used as a Mind Map sheet, besides preparing stationery like markers with attractive colors.

2. Write down the themes, ideas, main ideas that have been thought of in the middle of the paper

3. Make branches that come from predetermined themes, ideas, or ideas which are the themes of the main theme

4. The branches that have been created can be developed into several new branches related to each sub-theme.

\section{Methodology}

This research method is an experiment with the form of quasi- experiment research and nonequivalent control group design research design which can be described as follows:

In this study there are two groups / classes which are experimental and control groups. The experimental group is the group that received the treatment of the application of the Mind Mapping method in the learning process, while the control group is not. The level of understanding of students is seen from the results of the post test conducted after the research conducted.

The procedure in this study consists of three stages, namely; preparation, implementation and evaluation (final stage). This research was conducted at the University of Bengkulu's Teacher Training and Education Faculty, especially in English Education Study Program. The population of this study was the third semester students of English Education Study Program who took English Morphology courses. There were recorded three classes A, B, and C in the third semester of English Education Study Program. Of the three classes, two classes will be taken as samples which act as the experimental class and the control class. Each class consists of approximately 35 students The data were collected through observation to see the involvement of students during the learning process, and test to see the students' ability to understand the material of use mind mapping 
method. The instruments used in this study are observation checklist and tests. The observation checklist is used at the group discussion and presentation stage.

The test was given at the end of learning activities in the form of multiple choice questions related to the material / chapter discussed. In this class the Introduction to English Morphology book will be used as a handbook.

Data in the form of student test results were analyzed statistically using the SPSS Statistics 17.0 application. To see how much the effectiveness of the application of mind mapping methods to student learning outcomes.

\section{RESEARCH RESULT}

In general, the results of the research showed a positive effect of the application of mind mapping method to the students understanding about topic being discussed. Based on the observation of learning process showed that college students were enthusiastic enough in learning activities. They were seemed to be more motivated for reading and understanding the topic being discussed. In group's activities, respectively the students attempted to understand the part that becomes his duty and attempted deliver understanding to another group member so every member group have the same understanding. In the presentation session, every group attempted to deliver their material with attractive mind mapping patterns so that the other groups could understand it easily. Each groups presented the same material with creativity mind mapping made. The display of mind mapping made in manual form ( created by using cardboard) and the form of a power point presentation slides created with very interesting so that make the students understand the material easily .

The results of the tests given to both groups experiment and control group showed considerable significant differences. The results can be seen as follow:

Table 1. Results test on class experiment (class A, 27 participants test)

Value Range
Category
Percentage 


\begin{tabular}{|c|c|c|}
\hline $89-100$ & excellent & $30 \%$ \\
\hline $72-86$ & Very well & $18 \%$ \\
\hline $55-68$ & well & $18 \%$ \\
\hline $37-51$ & less & $26 \%$ \\
\hline Less of 37 & Very less & $0 \%$ \\
\hline
\end{tabular}

Table 2. Results Test on class control (Class B, 28 participants test)

\begin{tabular}{|c|c|c|}
\hline Value Range & Category & Percentage \\
\hline $89-100$ & excellent & $3.5 \%$ \\
\hline $72-86$ & Very well & $32 \%$ \\
\hline $55-68$ & well & $18 \%$ \\
\hline $37-51$ & less & $25 \%$ \\
\hline Less of 37 & Very less & $3.5 \%$ \\
\hline
\end{tabular}

\section{DISCUSSION}

In this research, there were four meetings which discussed two different topics. On the first meeting on class experiment, lecturer gave away explanation about material to be discussed from the English Morphology handbook. Then lecturer explained about mind mapping technique in understanding the material. Next, students were divided into 8 groups, each of which group assigned to prepare presentation in the form of manual mind mapping. On the second meeting, each groups presented the results of group discussion by using manual mind mapping chart (hand written in the large paper). In the presentation, students were displaying mind mapping creations 
creativity agreed that the use of mind mapping technique help them in understanding the concept of English Morphology courses especially on inflectional and derivational morphology material.

The same thing was done in discussing the topics about derivational morphology. However on this topic, the students were asked to make mind mapping with power point slides presentation. The power point slides that created by the students were very diverse and creative since they could apply the technology in creating a very attractive and interesting slides. Because each groups explained the same material, the students seemed to be more and more understand about the concepts discussed on derivational morphology material.

The next stage was giving the test about inflectional and derivational morphology. Tests were given in the form of group word which were 3 of them group derivation or inflection. Students were requested to choose one word that are not including to another word group. Example question;
1. a) write
b) written
c) rewrite
d) wrote

On question in above, choices $a, b$, and $d$ are the process of inflectional word formation. Then, one that do not include to the group of inflection is choice c)
2.a) commission
b) confusion
c) organization
d) emotion

In contrast, the second problems consist of derivational morphology process ( choice a, b, and c) so that the one which is not include as derivational morphology is $\mathrm{d}$.

There were 30 problems that should be solved by the students. The words are taken from example words discussed on chapter inflection and derivation from book An Introduction to English Morphology which is used as a handbook in this course. 
From the results of the test that can be seen in table 1 and 2, it showed that students on experiment class performed better than class control . Among 27 students , 8 students or $30 \%$ of them get excellent category. It means that students were able to answer right more than 26 questions out of 30 questions . Even 2 of them were able to answer all question right . Each 18\% were on very well category and good and $25 \%$ were at category enough. There were no students in the lowest category. While on class control only 1 student or $3.5 \%$ of 28 students who got excellent category with value of 89 . Meanwhile on category very well and well each 32 and $34 \%$. On category enough $25 \%$ and the lowest category $3.5 \%$

A striking difference seen on excellent category where on class experiment reaching $30 \%$ temporarily on the control class is only $3.5 \%$. Besides that on experiment class there were no students with the lowest category while on the control class there were $3.5 \%$. The result display picture that the results test on experiment class was far better than control class.

\section{CONCLUSION}

From the results and discussion above, it can be concluded that the research about the application of mind mapping technique in teaching theoretical subject in this case English Morphology help students in understanding the concept of word formation in English, especially on inflectional and derivational morphology. Moreover, this technique proved to make students to be more motivated reading and understanding the material. Group work was also help students to be more enthusiastic in delivering their understanding. In other words, collaborative learning and student centers are also implemented. The test result also proved that mind mapping technique is capable to improve students understanding which is shown from the test result where the experiment class achieve far better than control class. 


\section{DAFTAR PUSTAKA}

Alamsyah, Maurizal. (2009). Kiat Jitu Meningkatkan Prestasi Dengan Mind Mapping. Yogyakarta : Mitra Pelajar

Casco, Mady. (2009). The use of Mind maps in the Teaching of Foreign Languages. Article.

Buran, Anne., Filyukof, Andrey. (2015) Mind Mapping Technique in Language Learning. XV International Conference " Linguistics and Cultural Studies: Traditions and Innovations”, LKTI 2015, 9-11 November 2015, Tomsk, Russia.

Buzan, Tony. (2012). Buku Pintar Mind Mapping. Jakarta: PT Gramedia Pustaka Utama.

Maisyarah, Buwono Sri, Syahrudin Husni. (2013). Efektivitas Metode Pembelajaran Mind Mapping Terhadap Hasil Belajar Siswa Pada Mata Pelajran Ekonomi SMA. Unpublished Thesis. Universitas Tanjung Pura.

Riswanto, Putra Pebri Prandika. ( 2012) The Use of Mind Mapping Strategy in the Teaching of Writing at SMAN3 Bengkulu, Indonesia. International Journal of Humanities and Social Science. Vol.2 No. 2 November 2012.

Saleh Andi.,(2009). Kreatif Mengajar dengan Mind Map.Bogor: CV Regina

Sugiyono. (2007). Metode Penelitian Kuantitatif, Kualitatif dan R\&D. Bandung.Alfabeta. 